\title{
Investigation of the Antioxidant Activity and Phenolic Compounds of Andricus quercustozae Gall and Host Plant (Quercus infectoria)
}

\author{
Musa Azmaz ${ }^{(D)}$, Özge Kılınçarslan Aksoy ${ }^{(D) *}$, Yusuf Katılmış ${ }^{(D)}$, \\ Ramazan Mammadov ${ }^{(D)}$
}

${ }^{1}$ Department of Veterinary, Laborant \& Veterinary Health Program, Acipayam Vocational High School, Pamukkale University, Denizli, Turkey

${ }^{2}$ Department of Biology, Faculty of Arts \& Science, Pamukkale University, Denizli, Turkey

${ }^{3}$ Department of Molecular Biology and Genetics, Faculty of Science, Muğla Sitkı Koçman University, Muğla, Turkey

\begin{abstract}
Andricus quercustozae (Bosc, 1792) is a cynipid gall wasp, which induces gall on oaks (Quercus spp.). It is known that both cynipid galls and oaks are used in traditional medicine. In this study, some biological characteristics of various extracts (acetone and ethanol) of A. quercustozae asexual gall and its host plant, Quercus infectoria Olivier, were investigated. The antioxidant capacities of the extracts were evaluated using radical scavenging activity (ABTS and DPPH assays), the $\beta$-carotene-linoleic acid method, the phosphomolybdenum method, and the reducing power (CUPRAC method). Total phenolics, flavonoid and tannin contents were measured in the gall and the oak leaf extracts. Moreover, ethanol extracts of the gall and the host plant were evaluated using HPLC for the composition of phenolics. Generally, the gall extracts (acetone and ethanol, respectively) exhibited the strongest radical scavenging (DPPH, $\mathrm{IC}_{50}$ value of acetone extract: 11.00 $\mu \mathrm{g} / \mathrm{mL}$ and $\mathrm{IC}_{50}$ value of ethanol extract: $8.67 \mu \mathrm{g} / \mathrm{mL}$; ABTS, $52.27 \mu \mathrm{g} / \mathrm{mL}$ and $44.97 \mu \mathrm{g} / \mathrm{mL}$ ) and antioxidant activities with the highest level of phenolics. The antioxidant activity of the gall extracts was in the range of 80.74 to $87.49 \%$ for $\beta$-carotene-linoleic acid method, while and it was ranged from 75.68 to 78.20 $\mathrm{mgAEs} / \mathrm{g}$ for phosphomolybdenum method. In the results of some antioxidant methods (ABTS and $\beta$-carotene-linoleic acid), it is observed that the host plant extract has values close or high to the gall extract. In this context, our results suggested that the cynipid gall extracts could be used as a natural agent in food, medicinal and pharmaceutical applications.
\end{abstract}

\section{INTRODUCTION}

Quercus infectoria belonging to the Fagaceae family is a small tree or a shrub widely grown in Turkey (Anatolia), Syria, Iran, and Greece. The oak is known as one of the medicinal plants, which has been traditionally used in oriental folks [1,2]. The gall wasps or cynipids (Cynipidae), which are known as the gall inducers, is a large group with roughly 1400 species

CONTACT: Özge Kılınçarslan Aksoy $\varangle$ oklncrsln@gmail.com @ Department of Biology, Faculty of Arts \& Science, Pamukkale University, Denizli, Turkey 
worldwide [3], and 151 cynipid species are also known from Turkey [4-6]. All cynipid species induce their galls on their host plant species, which are mostly the oaks (Fagaceae), Rosaceae, Lamiaceae, Asteraceae and Papaveraceae. The galls are structures formed by plants entirely for the benefit of the gall inducer. The gall provides nourishment, shelter, and protect the cynipids [3]. Besides, the gall has been used in folk medicine for having various therapeutic properties since ancient times [7]. In the ancient Sumerian (5000 BC) and Babylonian periods, the galls of Andricus infectorius (Hartig) (known as Turkish Gall) were presented in the prescriptions for typhoid cure. Furthermore, it was used in the cure of bleeding and respiratory diseases in ancient Syria [8, 9]. In Traditional Uyghur Medicine, it is seen that the gall (A. infectorius) was widely used in the cure of intestinal dysmotility, dysentery, functional enteritis, hemorrhagic sores, alopecia areata, dental caries, periodontitis, halitosis, pharyngolaryngitis and tympanitis $[10,11]$. According to last two decades pharmacological researches, the various biological activities of the oak galls such as antibacterial, antiviral, antifungal, antioxidant, astringent, antidiabetic, antiparkinsonian, antitumor, antidiabetic, local anaesthetic, antipyretic, antiinflammatory and many more $[10,12-16]$ have been revealed. In addition, there are many types of research on antioxidant activities, total phenolic and flavonoid compounds of A. infectorius galls. The gall extracts possess a strong antioxidant activity against free radicals because of the greater amount of phenolic and flavonoid compounds [17-23].

Previous phytochemical investigations have shown that the oak galls contain high amounts of tannin (50-70\%) [24-28]. Gallic acid, ellagic acid and some sugars are the main constituents found in the cynipid galls in addition to tannin [29-31]. The amount of tannin is more concentrated in gall tissues than leaf tissues. The tissues with lower tannins are used as nutrients by cynipid larvae [32-34]. There is a highly significant positive correlation between the tannin level in oak and gall wasp diversity or abundance. The cynipids, along with their defence development against oak tannins, used them for their benefit. Tannins protect the cynipid larvae to fungal pathogens, hyper-parasites, leaf herbivores and some pathogenic factors [35].

The study aimed to investigate the amounts of the total secondary metabolites of the gall and host plant extracts. Besides, it reveals some biological characteristics (antioxidant activities) and phenolic components of all extracts for future investigations. In this context, some biological characteristics of the oak gall and the host plant are considered to be an accessible and important data source for antioxidant activity. In short, to determine in which areas (like the food industry, medicinal and pharmaceutical) the benefits of the cynipid gall used in traditional medicine, can be used.

\section{MATERIAL and METHODS}

\subsection{Collection and Preparation of Gall and Host Plant Extracts}

Andricus quercustozae (Bosc, 1792) asexual gall and the leaves of the host oak (nongalled leaves), $Q$. infectoria, were collected from Denizli, Turkey in May 2015. The species identified by the Entomology Laboratory in Pamukkale University. The galls and leaves of the host oak were dried in the shadow, broken into small pieces with an electric blender. And then gall and leaves were extracted with acetone and ethanol using the previous method [36] and stored in Secondary Metabolite Laboratory, Pamukkale University, Turkey.

\subsection{Determination of Total Bioactive Components}

\subsubsection{Quantification of Total Phenolic Content}

The Folin-Ciocalteu method [37] with slight modification was used to determine the total phenolic contents of each extract. The sample solution $(1 \mathrm{mg} / \mathrm{mL})$ was mixed with diluted Folin-Ciocalteu reagent $(1 \mathrm{~mL})$ and $\mathrm{dH}_{2} \mathrm{O}(46 \mathrm{~mL})$. After $3 \mathrm{~min}$, sodium carbonate solution (3 
$\mathrm{mL}, 2 \%, \mathrm{Na}_{2} \mathrm{CO}_{3}$ ) was added. The absorbance of the mixture was measured at $760 \mathrm{~nm}$ after the incubation (in the dark, 2 hours, room temperature). The total phenolic content was expressed as equivalents of gallic acid (mgGAEs/g).

\subsubsection{Quantification of Total Flavonoid Content}

The total flavonoid contents of each extract were analysed according to the method [38]. Briefly, aluminium trichloride $\left(1 \mathrm{~mL}, 2 \% \mathrm{AlCl}_{3}\right)$ was mixed with the same volume of extract solution $(2 \mathrm{mg} / \mathrm{mL})$. The absorbance was measured at $415 \mathrm{~nm}$ after the incubation $(10 \mathrm{~min}$, room temperature). The total flavonoid content was expressed as equivalents of quercetin (mgQEs/g).

\subsubsection{Quantification of Total Tannin Content}

The vanillin method [39] with slight modification was used for analysing the total tannin content. The solution $(0.5 \mathrm{~mL})$ was mixed with vanillin reagent $\left(1.5 \mathrm{~mL}, 1 \%\right.$ in $\left.7 \mathrm{M} \mathrm{H}_{2} \mathrm{SO}_{4}\right)$ in an ice bath. The solution absorbance was measured at $500 \mathrm{~nm}$ after the incubation $(15 \mathrm{~min}$, room temperature). The total tannin content was expressed as equivalents of (+)-catechin (mgCEs/g).

\subsection{Radical Scavenging Activity}

\subsubsection{Determination of DPPH Radical-Scavenging Activity}

The radical scavenging activity of the extracts was determined using the method [40]. Different concentration ( 5 to $25 \mu \mathrm{g} / \mathrm{mL}$ ) of the extracts $(1 \mathrm{~mL}$ ) was mixed with $4 \mathrm{~mL}$ of DPPH (2,2-diphenyl-1-picrylhydrazyl) radical methanolic solution. The absorbance was measured at $517 \mathrm{~nm}$ after $30 \mathrm{~min}$. Synthetic antioxidant BHT (butylated hydroxytoluene) was used as a positive control. The results were expressed as $\mathrm{IC}_{50}$ values.

\subsubsection{Determination of ABTS Radical-Scavenging Activity}

The method [41] with slight modification was used to determine the radical scavenging activity of the extracts. ABTS (2,2'-azino-bis(3-ethylbenzothiazoline-6-sulfonic acid)) cation was produced by reacting ABTS solution $(7 \mathrm{mM})$ with potassium persulfate $(2.45 \mathrm{mM})$ and then the mixture to stand in dark (12-16 hours, at the room temperature). The mixture was diluted with ethanol to give an absorbance of $0.700 \pm 0.02$ units at $734 \mathrm{~nm}$ for the study. The extract solution $(1 \mathrm{~mL})$ and ABTS solution $(2 \mathrm{~mL})$ were mixed. The mixture absorbance was read at $734 \mathrm{~nm}$ after the incubation period (15 min, at room temperature). The results were expressed as $\mathrm{IC}_{50}$ values.

\subsection{Total Antioxidant Activity}

\subsection{1. $\beta$-Carotene-Linoleic Acid Method}

The total antioxidant activity of the extracts was analyzed using the $\beta$-carotene-linoleic acid method [42] with slight modifications. $\beta$-Carotene $(0.2 \mathrm{mg})$ was dissolved in chloroform $(1 \mathrm{~mL})$ and added linoleic acid $(20 \mu \mathrm{L})$ and Tween-20 $(200 \mathrm{mg})$. The chloroform was evaporated using a rotary evaporator. The mixture was diluted with $\mathrm{dH}_{2} \mathrm{O}(100 \mathrm{~mL})$. As soon as the emulsion $(4.8 \mathrm{~mL})$ and $1 \mathrm{~mL}$ extracts $(1 \mathrm{mg} / \mathrm{mL})$ were placed into test tubes, initial absorbance was measured at $470 \mathrm{~nm}$. The measurement was carried out at $30 \mathrm{~min}$ intervals for $2 \mathrm{hr}$. BHA and BHT were used as standards. The antioxidant activity was calculated using the equation below:

$$
A A=\left[1-\left(\frac{A_{0}-A_{t}}{A_{0}^{\circ}-A^{\circ}}\right)\right] \times 100
$$

Where $A_{0}$ and $A_{0}^{o}$ are the absorbance values measured at the initial incubation time for samples and control, respectively. While $A_{t}$ and $A^{o}{ }_{t}$ are the absorbance values measured in the samples or standards and control at $2 \mathrm{hr}$. 


\subsubsection{Phosphomolybdenum Method}

The phosphomolybdenum method [43] with slight modification was used to determine the antioxidant activity of the extracts. Extract solution $(0.3 \mathrm{~mL})$ was mixed with $3 \mathrm{~mL}$ of reagent solution $(0.6 \mathrm{M}$ sulfuric acid, $28 \mathrm{mM}$ sodium phosphate and $4 \mathrm{mM}$ ammonium molybdate). The mixture absorbance was read at $695 \mathrm{~nm}$ after the incubation period (90 min, at $95{ }^{\circ} \mathrm{C}$ ). The total antioxidant capacity was expressed as equivalents of ascorbic acid (mgAEs/g).

\subsection{Reducing Power}

\subsubsection{Activity Cupric Ion Reducing (CUPRAC) Method}

The method [44] was used to determine the cupric ion reducing activity (CUPRAC). Extract solution $(0.5 \mathrm{~mL})$ was added to premixed reaction mixture containing $\mathrm{CuCl}_{2}(1 \mathrm{~mL}, 10$ $\mathrm{mM})$, neocuproine ( $1 \mathrm{~mL}, 7.5 \mathrm{mM})$ and $\mathrm{NH}_{4} \mathrm{Ac}$ buffer $(1 \mathrm{~mL}, 1 \mathrm{M}, \mathrm{pH} 7.0)$. Similarly, a blank was prepared by adding sample solution $(0.5 \mathrm{~mL})$ to the premixed reaction mixture $(3 \mathrm{~mL})$ without $\mathrm{CuCl}_{2}$. The mixture and blank absorbances were measured at $450 \mathrm{~nm}$ after the incubation period (30 min, at room temperature). The absorbance of the blank was subtracted from that of the sample. CUPRAC activity was expressed as equivalents of Trolox (mgTEs/g).

\subsection{Quantification of the Phenolic Compounds by HPLC}

Phenolic compounds were analyzed by high performance liquid chromatography (HPLC) according to the method [45] with some modification. Detection and quantification were performed with a diode array detector (SPD-M20A), a LC-20AT pump, a CTO-10ASVp column heater, SIL-20ACHT auto sampler, SCL-10Avp system controller and DGU-14A degasser. The mobile phases were A: $3.0 \%$ formic acid in distilled water and B: methanol. Methanol was used to dissolve samples, and then $20 \mu \mathrm{L}$ of this solution was injected into the column. Gallic acid, 3,4-dihydroxybenzoic acid, 4-hydroxybenzoic acid, 2,5-dihydroxybenzoic acid, chlorogenic acid, vanillic acid, epicatechin, caffeic acid, $p$-coumaric acid, ferulic acid, rutin, ellagic acid, naringin, quercetin, and cinnamic acid were used as standards. The differentiation and quantitative analysis were made by comparing the standards. The quantity of each phenolic compound was expressed as $\mu \mathrm{g}$ per gram of the extract.

\subsection{Statistical Analysis}

The SPSS Statistical Package program were used to analyze the results. The results were presented as mean \pm std. Differentiations between the extracted groups were tested using Analysis of Variance and Tukey method were performed $(p<0.05)$.

\section{RESULTS and DISCUSSION}

\subsection{Determination of Total Bioactive Components}

The calibration curve generated from the analysis of the standard (gallic acid) was linear with $y=0.0016 x+0.0407 ; r^{2}=0.983$. The A. quercustozae gall extracts showed the highest phenolic content, acetone $(479.56 \pm 45.36 \mathrm{mgGAE} / \mathrm{g})$ and ethanol $(437.27 \pm 3.14 \mathrm{mgGAE} / \mathrm{g})$, while $Q$. infectoria extracts showed the lowest contents. Among the studied extracts, total phenolic content ranged from 79.35 to $479.56 \mathrm{mgGAE} / \mathrm{g}$ (Table 1). Phenolic contents of the gall extracts were found to be more than the extracts of host oak $(Q$. infectoria). In addition, there were no differences between the acetone and ethanol extracts for each species ( $>0.05)$, but the gall extracts and host plant extracts were found to be statistically different from each other $(p<0.05)$.

In the present study, total flavonoid contents were analysed with the spectrophotometric method [38], and the flavonoid contents ranged from 33.19 to $110.28 \mathrm{mgQE} / \mathrm{g}$ (Table 1). Statistical differences among each group were found $(p<0.05)$. 
Table 1. Total Phenolic, Flavonoid and Tannin Contents (mean \pm SD) of the Extracts.

\begin{tabular}{ccccc}
\hline Species & Solvent & $\begin{array}{c}\text { Total Phenolic Content } \\
(\mathrm{mgGAEs} / \mathrm{g})\end{array}$ & $\begin{array}{c}\text { Total Flavonoid } \\
\text { Content }(\mathrm{mgQEs} / \mathrm{g})\end{array}$ & $\begin{array}{c}\text { Total Tannin Content } \\
(\mathrm{mgCEs} / \mathrm{g})\end{array}$ \\
\hline $\begin{array}{c}\text { A. quercustozae } \\
\text { asexual gall }\end{array}$ & Acetone & $479.56 \pm 45.36^{\mathrm{b}}$ & $47.84 \pm 3.06^{\mathrm{b}}$ & $23.10 \pm 1.22^{\mathrm{b}}$ \\
E. infectoria leaf & Acetone & $87.90 \pm 8.97^{\mathrm{a}}$ & $33.19 \pm 1.91^{\mathrm{a}}$ & $7.03 \pm 0.02^{\mathrm{a}}$ \\
& Ethanol & $79.35 \pm 6.13^{\mathrm{a}}$ & $110.28 \pm 3.47^{\mathrm{d}}$ & $34.04 \pm 0.75^{\mathrm{c}}$ \\
\end{tabular}

$\overline{\mathrm{GAE}}=$ Gallic Acid Equivalents; $\mathrm{QE}=$ Quercetin Equivalents; CE = Catechin Equivalents; Data were given as the mean of the measurements \pm std. The letters after the mean values in each column refers to statistically different than the others $(\mathrm{p}<0.05)$.

Tannin content was analysed using the vanillin method and these results were evaluated as catechin equivalents. The total tannin content of the extracts varies from 7.03 to 34.04 $\mathrm{mgCE} / \mathrm{g}$ (Table 1). There were no differences ( $p>0.05$ ) between the acetone and ethanol extracts of the host plant, but the gall extracts and host plant extracts were found to be statistically different from each other ( $\mathrm{p}<0.05$ ). Unlike phenolic compounds, Q. infectoria extracts showed the highest flavonoid and tannin content while the gall extracts showed the lowest contents. These results suggested that the phenolic, flavonoid and tannin contents were best extracted with acetone for both the gall and the host plant (Table 1).

Secondary metabolite constituents are known as phenolic, flavonoid and tannin etc. that serve as powerful antioxidants [46]. Moreover, there are important biological properties as antiallergenic, antimicrobial, antiartherogenic, antithrombotic, antiinflammatory, vasodilatory and cardioprotective effects [47-50]. Similar to the previous studies [21, 51-53], this study also shows that the cynipid gall and the host plant contain high amounts of phenolic, flavonoid and tannin.

\subsection{Radical Scavenging Activity (DPPH and ABTS Assays)}

The free radical scavenging activities of the samples of A. quercustozae gall and $Q$. infectoria leaves were tested by DPPH and ABTS assays. The DPPH and ABTS are known as radicals, they can be readily undergone scavenging by an antioxidant $[54,55]$. The lower $\mathrm{IC}_{50}$ reflected a higher antioxidant activity in both assays (Table 2). In DPPH assay, the gall extracts more than the leaf extracts, have stronger scavenging activity. Among all the extracts, only ethanolic gall extract exhibited the highest radical scavenging capacity with $\mathrm{IC}_{50}: 8.67 \mu \mathrm{g} / \mathrm{mL}$, followed by acetonic gall extract. The lowest scavenging activity was observed in ethanolic leaf extract with a very high $\mathrm{IC}_{50}$ value of $54.37 \mu \mathrm{g} / \mathrm{mL}$. The ABTS scavenging capacity of the extracts was determined and $\mathrm{IC}_{50}$ values are given in Table 2.

The extracts showed scavenging activities in the range of 19.75 to $52.27 \mu \mathrm{g} / \mathrm{mL}$. The acetonic leaf extract showed significantly stronger ABTS scavenging capacity $\left(\mathrm{IC}_{50}: 19.75 \pm\right.$ $0.92 \mu \mathrm{g} / \mathrm{mL}$ ) than that of all other extracts ( $\mathrm{p}<0.05$ ). In compared extracts, A. quercustozae gall extracts had higher antioxidant capacity than $Q$. infectoria leaf extracts. The results of the strong radical scavenging capacity of the gall extracts are related to the high concentration of phenolic compounds in the gall extracts (Tables 1,2 ).

\subsection{Total Antioxidant Activity ( $\beta$-carotene-linoleic Acid and Phosphomolybdenum Methods)}

The total antioxidant capacities of the extracts were evaluated by using $\beta$-carotenelinoleic acid assay. The extracts of both samples exhibited generally high antioxidant activities (Table 2). However, the leaf extracts had strong antioxidant activity $(91.05 \pm 1.29 \%$ and 89.45 $\pm 1.72 \%)$ more than the gall extracts $(80.74 \pm 7.39 \%$ and $87.49 \pm 1.27 \%)$. When compared with the inhibition values of all extracts, the acetone extract of the leaf $(91.05 \pm 1.29 \%)$ had a higher 
value than others, but lower than synthetic antioxidants (BHA and BHT). In phosphomolybdenum assay, the extracts obtained from the gall had a higher antioxidant capacity than leaf extracts $(p<0.05)$. Furthermore, the acetone extracts showed the highest antioxidant activity while the ethanol extracts showed the lowest activity (Table 2). Therefore, both the gall and the leaf extracts can be considered as natural inhibitors in the food industry. It must be the first study to compare the antioxidant capacities of the gall and the host plant.

Table 2. Antioxidant Properties of the Extracts.

\begin{tabular}{|c|c|c|c|c|c|c|}
\hline Species & Solvent & $\begin{array}{l}\text { ABTS }\left(\mathrm{IC}_{50}\right) \\
(\mu \mathrm{g} / \mathrm{mL})\end{array}$ & $\begin{array}{c}\mathrm{DPPH} \\
\left(\mathrm{IC}_{50}\right) \\
(\mu \mathrm{g} / \mathrm{mL})\end{array}$ & $\begin{array}{c}\beta \text {-carotene } \\
\text { /linoleic acid } \\
\text { method }(\%)\end{array}$ & $\begin{array}{l}\text { Phosphomolybdenum } \\
\text { method (mgAEs/g) }\end{array}$ & $\begin{array}{l}\text { CUPRAC } \\
\text { assay } \\
\text { (mgTEs/g) }\end{array}$ \\
\hline \multirow{2}{*}{$\begin{array}{l}\text { A. quercustozae } \\
\text { asexual gall }\end{array}$} & Acetone & $52.27 \pm 4.49^{c}$ & $11.00 \pm 0.39^{\mathrm{a}}$ & $80.74 \pm 7.39^{\mathrm{a}}$ & $78.20 \pm 1.63^{c}$ & $237.74 \pm 5.55^{\mathrm{c}}$ \\
\hline & Ethanol & $44.97 \pm 2.56^{\mathrm{bc}}$ & $8.67 \pm 0.58^{a}$ & $87.49 \pm 1.27^{\mathrm{ab}}$ & $75.68 \pm 0.44^{\mathrm{c}}$ & $245.82 \pm 1.06^{\mathrm{c}}$ \\
\hline \multirow{2}{*}{ Q. infectoria leaf } & Acetone & $19.75 \pm 0.92^{\mathrm{a}}$ & $46.16 \pm 4.60^{b}$ & $91.05 \pm 1.29^{\mathrm{b}}$ & $57.83 \pm 3.55^{\mathrm{b}}$ & $146.73 \pm 1.77^{\mathrm{a}}$ \\
\hline & Ethanol & $40.71 \pm 2.19^{b}$ & $54.37 \pm 3.61^{\mathrm{c}}$ & $89.45 \pm 1.72^{\mathrm{ab}}$ & $37.76 \pm 2.52^{\mathrm{a}}$ & $155.62 \pm 2.29^{\mathrm{b}}$ \\
\hline BHA & - & $\mathrm{nt}$ & nt & $100.00 \pm 0.00$ & nt & $\mathrm{nt}$ \\
\hline BHT & - & $12.05 \pm 0.44$ & $18.00 \pm 0.30$ & $92.89 \pm 0.52$ & $\mathrm{nt}$ & $\mathrm{nt}$ \\
\hline
\end{tabular}

AE: Ascorbic Acid Equivalents; TE: Trolox Equivalents; nt: not tested; Data were given as the mean of the measurements \pm std. The letters after the mean values in each column refers to statistically different than the others $(p<0.05)$.

Table 3. Phenolic Compounds in the Ethanolic Extracts ( $\mu \mathrm{g} / \mathrm{g}$ extract).

\begin{tabular}{ccccc}
\hline No. & Phenolic Component & RT $(\mathrm{min})$ & A. quercustozae asexual gall & Q. infectoria leaf \\
\hline 1 & Gallic Acid & 6.8 & 113.384 & 46.337 \\
2 & 3,4-dihydroxybenzoic acid & 10.7 & 210.835 & 84.87 \\
3 & 4-hydroxybenzoic acid & 15.7 & 383.299 & 100.285 \\
4 & 2,5-dihydroxybenzoic acid & 17.2 & 6002.886 & 2181.12 \\
5 & Chlorogenic acid & 18.2 & 132.297 & 40.314 \\
6 & Vanillic acid & 19.2 & 1002.53 & 360.975 \\
7 & Epicatechin & 21.3 & 27286.511 & 3679.685 \\
8 & Caffeic acid & 22.7 & 31979.335 & 8982.126 \\
9 & p-Coumaric acid & 26.1 & 2.203 & 89.31 \\
10 & Ferulic acid & 30.1 & 1.311 & 90.41 \\
11 & Rutin & 45.6 & $<$ LOD & $<$ LOD \\
12 & Ellagic acid & 47.7 & 2854.833 & 2635.375 \\
13 & Naringin & 49.7 & 29.915 & 911.861 \\
14 & Quercetin & 70.4 & $<$ LOD & 285.237 \\
15 & Cinnamic acid & 71.1 & 6.316 & 97.219 \\
\hline
\end{tabular}

LOD = Limit of Detection; RT: Retention Time.

\subsection{Reducing Power (CUPRAC Method)}

$\mathrm{Cu}^{2+}$ reduction is used to determine electron donation activity which is known an important mechanism of antioxidant. Therefore, in order to analyse extracts' electron-donating power, their ability to reduce $\mathrm{Cu}$ (II) was tested. The high values of TEs reflected a high reducing activity. The reducing power activities of the extracts are presented in Table 2 . When compared to the cupric reducing ability of all extracts, the ethanol extracts had a high cupric reduction potential for both samples. Moreover, the gall extracts exhibited higher values than the leaf extracts $(\mathrm{p}<0.05)$. The high reducing power of the gall extracts might relate to the high phenolic compounds that act as electron donors. 
There are investigations on the antioxidant activities of both the host plant [51] and the cynipid gall [17-20, 22, 56, 57]. For the first time, a different species (A. quercustozae) and its host plant $(Q$. infectoria) were compared with this study. This and similar studies should reveal the important biological characteristics of many cynipid galls and host plant, which has been used since ancient times against many diseases, in terms of human health.

\subsection{Phenolic Composition (HPLC)}

In the study, the phenolic components of the ethanolic extracts of A. quercustozae asexual gall and $Q$. infectoria leaf were determined using the HPLC method (Table 3). For both species' extracts, caffeic acid has the highest concentration followed by epicatechin. Caffeic acid and epicatechin are abundant in medicinal plants and possess many biological effects such as antioxidant, anti-aging [58, 59]. Moreover, other phenolic compounds found in the extracts such as gallic acid also possess beneficial effects on human health. Radical scavenging activity can thus be explained by the presence of epicatechin and caffeic acid.

\section{CONCLUSION}

The results reported in this study revealed that tested total phenolic compounds were significantly found more in the gall extracts. However, the gall extracts were strong radical scavenging because of the highest level of phenolics. The non-galled leaves extracts have the highest flavonoid and tannin contents while the gall extracts showed the lowest contents. These results suggested that the phenolic, flavonoid and tannin contents were best extracted with acetone for both the gall and the host plant. Due to the high antioxidant activities were observed, it is suggested that they can be used as a natural agent in food, medicinal and pharmaceutical applications. This study clearly indicates that the gall derived remedies may have distinct therapeutic effect as compared with analogues produced from other parts of the host plant. The galls can also be used for the prevention and treatment of various diseases. Although cynipid diversity is rich in worldwide, only gall extracts of a few species have been studied so far. Further studies are necessary to determine some biological characteristics of other cynipid galls extract for the food industry and medicine.

\section{Acknowledgements}

We would like to thank crew in Secondary Metabolite Laboratory, Pamukkale University, which helped during the study.

\section{Declaration of Conflicting Interests and Ethics}

The authors declare no conflict of interest. This research study complies with research publishing ethics. The scientific and legal responsibility for manuscripts published in IJSM belongs to the authors.

\section{Orcid}

Musa Azmaz (DiD https://orcid.org/0000-0002-9621-9909

Özge K1lınçarslan Aksoy (D) https://orcid.org/0000-0003-4944-1029

Yusuf Katılmış (D) https://orcid.org/0000-0003-0880-1489

Ramazan Mammadov (D) https://orcid.org/0000-0003-2218-5336

\section{REFERENCES}

[1]. Dar, M.S., Ikram, M., Fakouhi, T. (1976). Pharmacology of Quercus infectoria. J. Pharm. Sci., 65, 1791-1794. doi:https://doi.org/10.1002/jps.2600651224

[2]. Jamzad, Z., Panahi, P., Mohammad, R.P., Fallha, A.M. (2012). Foliar epidermal morphology in Quercus (subgenus Quercus, section Quercus) in Iran. Acta Bot. Croat., 71, 95-113. doi:https://doi.org/10.2478/v10184-010-0029-y 
[3]. Ronquist, F., Nieves-Aldrey, J.L., Buffington, M.L., Liu, Zh., Liljeblad, J., Nylander, J.A.A. (2015). Phylogeny, Evolution and Classification of Gall Wasps: The Plot Thickens. PLoS ONE, 10, 1-40. doi:https://doi.org/10.1371/journal.pone.0123301

[4]. Azmaz, M., Katılmış, Y. (2017). Updated species list of Cynipidae (Hymenoptera) from Turkey. Zootaxa, 4303, 361-378. doi: https://doi.org/10.11646/zootaxa.4303.3.3

[5]. Azmaz, M., Katılmış, Y. (2020). A new species of herb gall wasp (Cynipidae, Aulacideini, Aulacidea) from Turkey. Zootaxa, 4747, 378-390. doi:https://doi.org/10.11646/zootaxa. 4747.2.9

[6]. Bayrak, S., Avcı, M. (2019). Gall forming Cynipini (Hymenoptera: Cynipidae) species in Isparta oak forests. Munis Entomology \& Zoology, 14, 552-564.

[7]. Imtiyaz, S., Ali, S.J., Tariq, M., Chaudhary, S.S., Aslam, M. (2013). Oak Galls: The Medicinal Balls. Journal of Pharmaceutical and Scientific Innovation, 2, 18-21.

[8]. Oefele, F. (1933). Vorgeschichte zur Cecidologie der klassischen Schriftsteller. (Ed.), K. Böhner. Geschichte der Cecidologie. Teil 1, Arthur Nemayer, Mittenwald [in German].

[9]. Schimitschek, E. (1953). Forestry insects of Turkey and its surrounding. (Ed.) A. Acatay. İstanbul University Publications, İstanbul, 471 pp. [in Turkish].

[10]. Iminjan, M., Amat, N., Li, X.H., Upur, H., Ahmat, D., He, B. (2014). Investigation into the Toxicity of traditional Uyghur medicine Quercus infectoria galls water extract. PLoS One, 9, e90756. doi:https://doi.org/10.1371/journal.pone.0090756

[11]. Wang, J.Y., Zhang, Q.H., Deng, X.M., Wang, D.C., Han, W.Y. (2007). Progress on pharmacological activities of Quercus infectoria galls. Shizhen Guoyi Guoyao, 18, 25702572.

[12]. Dar, M.S., Ikram, M. (1979). Studies on Quercus infectoria; isolation of syringic acid and determination of its central depressive activity. Planta Med, 35, 156-161. doi:https://doi.org/10.1055/s-0028-1097197

[13]. Everest, A., Öztürk, E. (2005). Focusing on ethnobotanical uses of plants in Mersin and Adana provinces (Turkey). J. Ethnobiol. Ethnomed., 1, 1-6. doi:https://doi.org/10.1186/ 1746-4269-1-6

[14]. Hamid, H., Kaur, G., Abdullah, S.T., Ali, M., Athar, M., Alam, M.S. (2005). Two new compounds from the galls of Quercus infectoria with nitric oxide and superoxide inhibiting ability. Pharm. Biol., 43, 317-323. doi:https://doi.org/10.1080/138802005909 51711

[15]. Hapidin, H., Abdullah, H., Soelaiman, I.N. (2012). The potential role of Quercus infectoria gall extract on osteoblast function and bone metabolism. Open Journal of Endocrine and Metabolic Diseases, 2, 82-88. doi:https://doi.org/10.4236/ojemd.2012.24 013

[16]. Yamunarani, K., Jaganathan, R., Bhaskaran, P., Govindaraju, R., Velazhahan, R. (2005). In vitro Antifungal Activity of a 29-kDa Glycoprotein Purified from the Galls of Quercus infetoria. Acta Phytopath. Entomol. Hungarica, 40, 43-54. doi:https://doi.org/10.1556/A Phyt.40.2005.1-2.6

[17]. Asif, M., Ansari, S.H., Rafiul Haque, Md., Kalam, N. (2012). Estimation of total phenolic, flavonoid contents and antioxidant activity in the nut galls of Quercus infectoria Olivier. Journal of Pharmacy Research, 5, 3855-3857.

[18]. Fathabad, A.E., Shariatifar, N., Mardani, K., Mohammadpourfard, I. (2015). Study on antibacterial and antioxidant activity of Oak gall (Quercus infectoria) extracts from Iran. International Journal of Current Science, 14, 44-50.

[19]. Hasmida, M.N., Liza, M.S., Nur Syukriah, A.R., Harisun, Y., Mohd Azizi, C.Y., Fadzilah Adibah, A.M. (2015). Total Phenolic Content and Antioxidant Activity of Quercus infectoria Galls Using Supercritical $\mathrm{CO}_{2}$ Extraction Technique and Its Comparison with Soxhlet Extraction. Pertanika J. Sci. Technol., 23, 287-295. 
[20]. Hasmida, M.N., Nur Syukriah, A.R., Liza, M.S., Mohd Azizi, C.Y. (2014). Effect of different extraction techniques on total phenolic content and antioxidant activity of Quercus infectoria galls. Int. Food Res. J., 21, 1075-1079.

[21]. Noori, M., Talebi, M., Ahmadi, T. (2015). Comparative Studies of Leaf, Gall and Bark Flavonoids in Collected Quercus brantii Lindl. (Fagaceae) from Lorestan Province, Iran. Int. J. Plant Res., 5, 42-49.

[22]. Nur Syukriah, A.R., Liza, M.S., Harisun, Y., Fadzillah, A.A.M. (2014). Effect of solvent extraction on antioxidant and antibacterial activities from Quercus infectoria (Manjakani). International Food Research Journal, 21, 1067-1073.

[23]. Rina, R., Rafiquzzaman, M., Hasmah, A. (2011). Spectrophotometric Determination of Total Phenol and Flavanoid Content in Manjakani (Quercus infectoria) Extracts. Health and the Environment Journal, 2, 9-13.

[24]. Basri, D.F., Tan, L.S., Shafiei, Z., Zin, N.M. (2012). In vitro Antibacterial Activity of Galls of Quercus infectoria Oliver against Oral Pathogens. Evid-Based Compl. Alt., 632796. doi:https://doi.org/10.1155/2012/632796

[25]. Cornell, H.V. (1983). The secondary chemistry and complex morphology of galls formed by the Cynipidae (Hymenoptera): why and how? The American Midland Naturalist, 110, 225-234. doi:https://doi.org/10.2307/2425263

[26]. Digrak, M., Alma, M.H., Ilcim, A., Sen, S. (1999). Antibacterial and antifungal effects of various commercial plant extracts. Pharm Biol, 37, 216-220. doi:https://doi.org/10.1076/ phbi.37.3.216.6307

[27]. Fatima, S., Farooqi, A.H.A., Kumar, R., Kumar, T.R.S., Khanuja, S.P.S. (2001). Antibacterial activity possessed by medicinal plants used in tooth powders. Journal of Medicinal and Aromatic Plant Sciences, 22, 187-189.

[28]. Ikram, M., Nowshad, F. (1977). Constituents of Quercus infectoria. Planta Med, 31, 8687. doi:https://doi.org/10.1055/s-0028-1097531

[29]. Charles, D.F.P. (1879). Materia medica and therapeutics-vegetable kingdoms. New York: William Wood and Company.

[30]. Vermani, A., Navneet., Prabhat. (2009). Screening of Quercus infectoria gall extracts as anti-bacterial agents against dental pathogens. Indian J. Dent. Res., 20, 337. doi:https://doi.org/10.4103/0970-9290.57380

[31]. Wiart, C., Kumar, A. (2001). Practical handbook of pharmacognosy. Malaysia: Pearson Education Malaysia SdnBhd.

[32]. Allison, S.D., Schultz, J.C. (2005). Biochemical Responses of Chestnut Oak to A Galling Cynipid. J. Chem. Ecol., 31, 1. doi:https://doi.org/10.1007/s10886-005-0981-5

[33]. Howes, F.N. (1953). Vegetable tanning materials. Butterworth, London.

[34]. Larew, H.G. (1982). A comparative anatomical study of galls caused by the major cecidogenetic groups with special emphasis on the nutritive tissue. PhD Dissertation, Oregon State University.

[35]. Taper, M.L., Case, T.J. (1987). Interactions between oak tannins and parasite community structure: Unexpected benefits of tannins to cynipid gall-wasps. Oecologia, 71, 254-261. doi:https://doi.org/10.1007/BF00377292

[36]. Mammadov, R., Ili, P., Ertem Vaizoğullar, H., Afacan Makasc1, A. (2011). Antioxidant Activity and Total Phenolic Content of Gagea fibrosa and Romulea ramiflora. Iran J. Chem. Chem. Eng., 30, 57-62.

[37]. Slinkard, K., Singleton, V.L. (1977). Total phenol analyses: Automation and comparison with manual methods. Am. J. Enol. Viticult., 28, 49-55.

[38]. Arvouet-Grand, A., Vennat, B., Pourrat, A., Legret, P. (1994). Standardization of a propolis extract and identification of the main constituents. J. Pharm. Belg., 49, 462-468. 
[39]. Bekir, J., Mars, M., Souchard, J.P., Bouajila, J. (2013). Assessment of antioxidant, antiinflammatory, anti-cholinesterase and cytotoxic activities of pomegranate (Punica granatum) leaves. Food Chem. Toxicol., 55, 470-475. doi:https://doi.org/10.1016/j.fct.2 013.01 .036

[40]. Wu, C., Chen, F., Wang, X., Kim, H.J., He, G., Haley-Zitlin, V., Huang, G. (2006). Antioxidant constituents in feverfew (Tanacetum parthenium) extract and their chromatographic quantification. Food Chem, 96, 220-227. doi:https://doi.org/10.1016/j.f oodchem.2005.02.024

[41]. Re, R., Pellegrini, N., Proteggente, A., Pannala, A., Yang, M., Rice-Evans, C. (1999). Antioxidant activity applying an improved ABTS radical cation decolorization assay. Free Radical Bio Med, 26, 1231-1237. doi:https://doi.org/10.1016/S08915849(98)00315 $-3$

[42]. Amin, I., Tan, S.H. (2002). Antioxidant activity of selected commercial seaweeds. Mal J Nutr, 8, 167-177.

[43]. Berk, S., Tepe, B., Arslan, S., Sarikurkcu, C. (2011). Screening of the antioxidant, antimicrobial and DNA damage protection potentials of the aqueous extract of Asplenium ceterach D.C. Afr J Biotechnol, 10, 8902-8908.

[44]. Apak, R., Güçlü, K., Özyürek, M., Karademir, S.E., Ercağ, E. (2006). The cupric ion reducing antioxidant capacity and polyphenolic content of some herbal teas. Int. J. Food Sci. Nutr., 57, 292-304. doi:https://doi.org/10.1080/09637480600798132

[45]. Caponio, F., Alloggio, V., Gomes, T. (1999). Phenolic compounds of virgin olive oil: influence of pastepreperation techniques. Food Chem., 64, 203-209. doi:https://doi.org/1 0.1016/S0308-8146(98)00146-0

[46]. Kaska, A., Deniz, N., Çiçek, M., Mammadov, R. (2018). Evaluation of Antioxidant Properties, Phenolic Compounds, Anthelmintic, and Cytotoxic Activities of Various Extracts Isolated from Nepeta cadmea: An Endemic Plant for Turkey. J. Food Sci., 83, 1552-1559. doi:https://doi.org/10.1111/1750-3841.14167

[47]. Alpınar, K., Ozyurek, M., Kolak, U., Guclu, K., Aras, C., Altun, M., Celik, S.E., Berker, K.I., Bektasoglu, B., Apak, R. (2009). Antioxidant Capacities of Some Food Plants Wildly Grown in Ayvalik of Turkey. Food Sci Technol Res, 15, 59-64. doi:https://doi.org/10.3136/fstr.15.59

[48]. K1lınçarslan, Ö., Mammadov, R. (2018). HPLC analysis and Antioxidant, Antibacterial and Cytotoxicity Activities of Various Solvent Extracts of Erysimum kotschyanum Gay. (Brassicaceae). J. Chem. Soc. Pakistan, 40, 707-714.

[49]. Middleton, E., Kandaswami, C., Theoharides, T.C. (2000). The effects of plant flavonoids on mammalian cells: Implications for inflammation, heart disease and cancer. Pharmacol Rev, 52, 673-751.

[50]. Rio, D.D., Rodriguez-Mateos, A., Spencer, J.P.E., Tognolini, M., Borges, G., Crozier, A. (2013). Dietary (poly)phenolics in human health: structures, bioavailability, and evidence of protective effects against chronic diseases. Antioxid Redox Sign, 18, 1818-1892. doi:https://doi.org/10.1089/ars.2012.4581

[51]. Kheirandish, F., Delfan, B., Mahmoudvand, H., Moradi, N., Ezatpour, B., Ebrahimzadeh, F., Rashidipour, M. (2016). Antileishmanial, antioxidant, and cytotoxic activities of Quercus infectoria Olivier extract. Biomed. Pharmacother., 82, 208-215. doi:https://doi. org/10.1016/j.biopha.2016.04.040

[52]. Paaver, U., Matto, V., Raal, A. (2010). Total tannin content in distinct Quercus robur L. galls. J. Med. Plants Res., 4, 702-705.

[53]. Pirozi, F., Adeli, K., Tavakoli, M. (2016). The study of Galls Growing on Oak tree's Importance in Producing Tannin (Case study in Ghalaie region in Lorestan Province). Adv. Biores., 7, 9-12. 
[54]. Leong, L.P., Shiu, G. (2002). An investigated of antioxidant capacity of fruits in Singapore markets. Food Chem., 76, 69-75. doi:https://doi.org/10.1016/S0308-8146(01)00251-5

[55]. Wang, L., Wang, Z., Li, X. (2013). Preliminary phytochemical and biological activities study of solvent extracts from a cold-field fruit-Malus baccata (Linn.) Borkh. Ind. Crop Prod., 47, 20-28. doi:https://doi.org/10.1016/j.indcrop.2013.02.029

[56]. Kaur, G., Athar, M., Alam, M.S. (2008). Quercus infectoria galls possess antioxidant activity and abrogates oxidative stress-induced functional alterations in murine macrophages. Chem-Biol Interact, 171, 272-282. doi:https://doi.org/10.1016/j.cbi.2007. 10.002

[57]. Khanavi, M., Sabbagh-Bani-Azad, M., Abdolghaffari, A.H., Vazirian, M., Isazadeh, I., Rezvanfar, M.A., et al. (2014). On the benefit of galls of Quercus brantii Lindl. in murine colitis: the role of free gallic acid. Arch. Med. Sci., 10, 1225-1234. doi:https://doi.org/10. 5114/aoms.2014.47831

[58]. Augustyniak, A., Bartosz, G., Cipak, A., Duburs, G., Horakova, L., Luczaj W., et al. (2010). Natural and synthetic antioxidants: an updated overview. Free Radical Res., 44, 1216-1262. doi:https://doi.org/10.3109/10715762.2010.508495

[59]. Thielecke, F., Boschmann, M. (2009). The potential role of green tea catechins in the prevention of the metabolic syndrome-a review. Phytochemistry, 70, 11-24. doi:https://doi.org/10.1016/j.phytochem.2008.11.011 